\title{
Examining the Factors Affecting Endodontic Therapy Failure
}

\author{
Shahla Shokrollahi Yancheshmeh ${ }^{1}$ \\ ${ }^{1}$ M.A. Rangoonwala College of Dental Science \& Research Center, Maharashtra University of Health Sciences, \\ India \\ Correspondence: Shahla Shokrollahi Yancheshmeh, M.A. Rangoonwala College of Dental Science \& Research \\ Center, Maharashtra University of Health Sciences, India. E-mail: Dr.shahlash@gmail.com
}

Received: September 30, 2019

Accepted: December 1, 2019

Online Published: March 30, 2020

doi:10.5539/jmbr.v10n1p1

URL: https://doi.org/10.5539/jmbr.v10n1p1

\begin{abstract}
The purpose of the study was to examine the factors affecting Endodontic Therapy Failure (ETF). The study was descriptive cross-sectional conducted at College of Dental Science \& Research Centre.

Dental school in Pune, India. In the present study, 90 patients were analyzed in the treatment ward. According to the results, the highest endodontic failure was observed in $41-50$ years age group $(41.11 \%)$ and the least was in 21-30 (24.44\%). According to the tooth type, most endodontic failures were observed in maxillary molars (44.4\%), mandibular molars $(20 \%)$ and maxillary premolars (15.5\%). Endodontic treatment by general dental practitioners (GDPs) showed the highest failure rate $(78.8 \%)$. The factors contributing to the most common endodontic problems were under-filled canals (33.3\%) and unfilled and missed canals (17.7\%). The study concluded that ETF occurred when the treatment was not according to the accepted standards. The main causes of ETF are microbial infection in the root canal system and these patients' not attending the specialists.
\end{abstract}

Keywords: Failure, Endodontic Therapy, Dentistry

\section{Introduction}

Endodontic therapy is a treatment sequence for the infected pulp of a tooth that eliminates infection and protects the infected tooth against the subsequent microbial invasion (Cohen \& Hargreaves, 2006). This therapy has been investigated in various studies (Farbod and Bolhari, 2018; Vigneshwar and Ramesh, 2017).The root canals and their paste shield are physical intra-dental holes that naturally exist in living connective tissue and blood vessels and together form the tooth pole (Nanci, 2012). Endodontic therapy includes the elimination of these structures, formation, cleaning cavity contamination with disinfectant solutions and the blockage of contaminated canals. Filling clean and contaminated canals is done using inert filler such as gutta-percha and typically zinc oxide eugenol (Marciano et al., 2011). Endodontics include both primary and secondary endodontic treatment as well as periradicular surgery, generally used for the teeth that can still survive (Setzer \& Kim, 2014; Kishen, Peters, Zehnder, Diogenes, \& Nair, 2016).

The keys to success in endodontic treatment are complete sealing of the root canal space and complete extraction of the infected root tissues of the pulp and microorganisms. This prevents recurrence and infection of the root canal space. ETF can be diagnosed according to clinical signs and symptoms and root canal radiographic findings. Many factors affect ETF, such as necrotic pulp of periradicular infection, periodontal disease, root fracture, broken instruments, mechanical perforations, root canal underfillings, and missed or unfilled canals (Siqueira, Rôças, \& Ricucci, 2019).

Endodontic treatment is not always successful (Feiz, 2017). Zimpolas et al. (2012) reported the most common causes of failure, as prosthetic failure (59.4\%), periodontal reasons $(32 \%)$, and endodontic reasons $(8.6 \%)$ (Tzimpoulas, Alisafis, Tzanetakis, \& Kontakiotis, 2012). Foss et al. (1999) reported that $43.5 \%$ of endodontic treatments were not successful and the most common reason for failure was root fracture (21.1\%) (Fuss, Lustig, $\&$ Tamse, 1999). According to Chen et al. (2008) and Zadik et al. (2008), the most common causes of failure were irreversible caries (46.4\% - 61.4\%) (Zadik, Sandler, Bechor, \& Salehrabi, 2008; Chen, Chueh, Hsiao, Wu, \& Chiang, 2008). Toreh et al. (2011) prepared a questionnaire for planning a prospective study to examine the causes of failure, where the main reasons were disease $(40.3 \%)$, endodontic failure $(19.3 \%)$, vertical root fractures (13.4\%), suspended fractures and irreversible crowns (15.1\%), irreversible caries (5.2\%), estrogen piercing (4.4\%) and prostheses (Touré, Faye, Kane, Lo, Niang, \& Boucher, 2011). This study discussed the factors mainly 
responsible for ETF, so to improve the quality of dental practice in terms of endodontic treatment, applications had to taken into account. Thus, the purpose of the study was to examine the factors affecting ETF.

\section{Methodology}

The study was descriptive cross-sectional conducted at College of Dental Science \& Research Centre

Dental school in Pune, India

. In the present study, 90 patients were analyzed in the treatment ward. Teeth with root fractures, periodontal and endodontic lesions, fractured crown, and irreversible and fractured teeth were excluded from the study. Faculty members of Endodontics Department of Dentistry participated in the study. Strindberg criteria (Strindberg, 1956) were used to judge the cases of endocrine failure. These criteria were as follows: 1) clinical symptoms such as pain, swelling and discharge of the sinus tract, and so on, 2) treatment of the sinus tract, and 3) increased size or incidence of new periadicular lesion. The proposed criteria of De-Moor et al. have been used to access root canal filling quality (De Moor, Hommez, De Boever, Delmé, \& Martens, 2000). Each case was fully radiographically examined with a magnifying glass for observation: untreated or missed canals, any unwanted injury, periapical condition of the involved tooth and root canal filling status. After careful clinical and radiographic evaluation of the involved teeth, the patients were scheduled for re-treatment. The patients were randomly selected from the clinic. They were divided into three age groups: Group 1 (20-30 years), Group 2 (31-40 years), and Group 3 (4150 years). Informed consent from the study subject and approval of this study were obtained from the College Ethics Committee. The collected data from the subjects to study on ETF were analyzed in SPSS, version 10, software as frequency and percentage of the results. Chi-square test was used to analyze the study parameters.

\section{Results}

Table 1. The relationship between ETF and dental practitioners and specialists

\begin{tabular}{llll}
\hline Therapist & Frequency & Frequency percentage & p-value \\
\hline Dental practitioners & 71 & $78.88 \%$ & $<0.001$ \\
Specialists & 19 & $21.1 \%$ & $<0.001$ \\
\hline
\end{tabular}

Table 2. The relationship between ETF and various ages

\begin{tabular}{lllll}
\hline & First group (21-30 years) & Second group (31 to 40 years) & Third group (41 to 50 years) & Total \\
\hline \multirow{2}{*}{ p-value } & $22(24.44 \%)$ & $31(34.44 \%)$ & $37(41.11 \%)$ & \multirow{2}{*}{$90(100 \%)$} \\
& $<0.001$ & $<0.001$ & $<0.001$ & \\
\hline
\end{tabular}

Table 3. Frequency percentage of ETF according to tooth type

\begin{tabular}{|c|c|c|c|c|c|c|c|c|c|}
\hline & $\begin{array}{l}\text { Max. } \\
\text { Anterior } \\
\text { tooth }\end{array}$ & $\begin{array}{l}\text { Min. } \\
\text { Canine } \\
\text { teeth }\end{array}$ & $\begin{array}{l}\text { Max. } \\
\text { Premolar }\end{array}$ & $\begin{array}{l}\text { Min. } \\
\text { Molar }\end{array}$ & $\begin{array}{l}\text { Max. } \\
\text { Anterior } \\
\text { tooth }\end{array}$ & $\begin{array}{l}\text { Min. } \\
\text { Canine } \\
\text { teeth }\end{array}$ & $\begin{array}{l}\text { Max. } \\
\text { Premolar }\end{array}$ & $\begin{array}{l}\text { Min. } \\
\text { Molar }\end{array}$ & Total \\
\hline Tooth type & 4 & 3 & 14 & 40 & 5 & 1 & 5 & 18 & 90 \\
\hline $\begin{array}{l}\text { Frequency } \\
\text { percentage }\end{array}$ & 4.4 & 3.3 & 15.5 & 44.4 & 5.5 & 1.1 & 5.5 & 20 & 100 \\
\hline
\end{tabular}

Table 4. Frequency percentage of the factors effective in ETF by radiographic evaluation

\begin{tabular}{lll}
\hline Endodontic Failure Factors & Frequency & Frequency percentage \\
\hline Broken instruments & 6 & 6.6 \\
Untreated canals & 11 & 12.2 \\
Unfilled and lost canals & 16 & 17.7 \\
Under-filled canals & 30 & 33.3 \\
Too moist canals & 9 & 10 \\
Holes & 5 & 5.5 \\
Poor crown restorations & 13 & 14.4 \\
\hline
\end{tabular}

Ninety patients aged 21-50 years were enrolled in the study. Endodontic treatment done by general dental practitioners has shown a high rate of failure (78.8\%), whereas the specialists have had the lowest rate $(21.1 \%)$. 
The highest endodontic failure was observed in the third age group (41\%) and the least was observed in the first age group (24.44\%). Concerning the type of tooth, most endodontic failures were in maxillary molars (44.4\%) and then mandibular molars $(20 \%)$ and maxillary premolars $(15.5 \%)$, whereas mandibular showed the least endodontic fractures $(1.1 \%)$. The factors that had identified the most endodontic problems were under-filled canals (33.3\%), unfilled and missed canals $(17.7 \%)$ and the factors least responsible for endodontic damage were mechanical holes $(5.5 \%)$ and broken instruments $(6.6 \%)$.

\section{Discussion}

ETF occurs when the treatment is not performed according to the accepted standards (Seltzer, Bender, \& Turkenkopf, 1963; Sundqvist, Figdor, Persson, \& Sjögren, 1998). The main causes of ETF are microbial infection in the root canal system and periradicular tissue (Nair, Sjögren, Krey, Kahnberg, \& Sundqvist, 1990; Lin, Skribner, \& Gaengler, 1992). The results in line with these studies showed that root canal filling quality is effective in endodontic treatment (Noor, Maxood, \& Kaleem, 2008; Nie \& Lin, 1999). Usually, as the result of inadequate preparation, dryness in root canal (more than $2 \mathrm{~mm}$ ) often leads to the lack of success in treatment. Chagal et al. showed that in case of $1 \mathrm{~mm}$ drop in length, there is a $14 \%$ chance of failure of endodontic treatment in teeth with apical periodontitis. The cause of pericardial tissue stimulation is the residual necrosis and pulp-infected tissue in inadequate and defective canals (Chugal, Clive, \& Spångberg, 2003). Unfilled canals were the second most common cause of unsuccessful endodontic treatment. These unfilled canals may be lost by the physician during root canal filling or may remain hidden during root canal excavation or he may be unable to find these canals. This was in line with the similar studies showing that due to the complexity of the root canal system, there was a risk of loss of root canal anatomy during endodontic therapy (Cantatore, Berutti, \& Castellucci, 2006).

Age is a significant factor in the success of endodontic treatment in the individuals. Results showed that most endodontic failures $(41.11 \%)$ were in the age group of 50-41 years, whereas the least endodontic failures (24.44\%) occurred in the age group of 21-30 years and their difference showed that the difference between the first and the third age groups was significant $(\mathrm{p}=0.011)$. The clear reason for failure in the age group of 41-50 was the calcified channels in the higher age groups. The second reason may be poor oral health and lack of proper patient-specialist interaction.

ETF depends on the location of the tooth, as well. Regarding this, most failures occur in the posterior teeth. The results showed that the greatest defects in endodontic treatment occurred in maxillary molars (44.4\%), mandibular molars $(20 \%)$ and maxillary premolars $(15.5 \%)$. The rate of endodontic failure was high $(5.5 \%)$ compared to maxillary injectors. The most general explanations on endodontic failure were untreated or unfilled canals after endodontic therapy. In mandibular injectors, the reason for the high ETF rate was the presence of extra canals not been treated during initial endodontic treatment (Cantatore, Berutti, \& Castellucci, 2006). Another reason could be the presence of curved and firm canals in multi-canal teeth, making successful endodontics treatment of these teeth difficult for specialists. The test statistics in the current study showed that this difference was significant ( $\mathrm{P}$ $=0.001$ ). Navar et al. reached similar findings in their study (Noor, Maxood, \& Kaleem, 2008). Skill, experience, and specialized training play an important role in the success of endodontic treatment. In this study, $78.8 \%$ of injured patients were treated by a GDP. The results of similar studies have indicated that failure rates can be significantly higher for those treated by a GDP and not by a specialist (Sjögren, Hägglund, Sundqvist, \& Wing, 1990; Weiger \& Axmann-Krcmar, 1998). Studies have indicated that endodontic treatment done by a GDP shows a success rate of $65-75 \%$, whereas endodontic therapy by specialists has a success rate over $90 \%$ (Eriksen, 1991). This difference in success rate may show a difference in technical quality of endodontic treatment by a GDP and specialist. By comparing GDPs and dentists, the study showed that test statistics were very significant $(\mathrm{P}=0.001)$. Of the limitations of the study was the lack of specific information about the experience of GDPs and their training.

The study concluded that ETF was mostly related to the lack of awareness and lack of continuing training periods by general dental practitioners. Moreover, ETF was due to the lack of proper specialized tools and the lack of proper training of these tools even when used by a dentist, complex anatomy of the involved teeth and these patients not visiting a specialist. Thus, it is suggested that the teeth with complex anatomy should be evaluated by high quality preoperative radiography and the GDPs should be encouraged to continue dental education, especially in the endodontics section.

\section{Conflict of interests}

The authors declare that there is no conflict of interests regarding the publication of this paper. 


\section{References}

Cantatore, G., Berutti, E., \& Castellucci, A. (2006). Missed anatomy: Frequency and clinical impact. Endodontic Topics, 15(1), 3-31.

Chen, S.-C., Chueh, L.-H., Hsiao, C. K., Wu, H.-P., \& Chiang, C.-P. (2008). First untoward events and reasons for tooth extraction after nonsurgical endodontic treatment in Taiwan. Journal of Endodontics, 34(6), 671-4.

Chugal, N. M., Clive, J. M., \& Spångberg, L. S. (2003). Endodontic infection: Some biologic and treatment factors associated with outcome. Oral Surgery, Oral Medicine, Oral Pathology, Oral Radiology, and Endodontology, 96(1), 81-90.

Cohen, S., \& Hargreaves, K. M. (2006). Pathways of the Pulp. (9 [sup] th ed., pp. 786-821). St Louis: Mosby.

De Moor, R., Hommez, G., De Boever, J., Delmé, K., \& Martens, G. (2000). Periapical health related to the quality of root canal treatment in a Belgian population. International Endodontic Journal, 33(2), 113-20.

Eriksen, H. M. (1991). Endodontology-epidemiologic considerations. Dental Traumatology, 7(5), 189-95.

Fuss, Z., Lustig, J., \& Tamse, A. (1999). Prevalence of vertical root fractures in extracted endodontically treated teeth. International Endodontic Journal, 32(4), 283-6.

Feiz, A., Nazeri, R., Karimi, K., Tayaran, S., Mosleh, H., Mojtahedi, N. (2017). The effects of surface treatments on root dentin analyzing microleakage of endodontically treated teeth restored with fiber posts. Annals of Dental Specialty, 5(4), 151-155.

Kishen, A., Peters, O. A., Zehnder, M., Diogenes, A. R., \& Nair, M. K. (2016). Advances in endodontics: Potential applications in clinical practice. Journal of Conservative Dentistry, 19(3), 199.

Lin, L. M., Skribner, J. E., \& Gaengler, P. (1992). Factors associated with endodontic treatment failures. Journal of Endodontics, 18(12), 625-7.

Marciano et al. (2011). Analysis of four gutta-percha techniques used to fill mesial root canals of mandibular molars. International Endodontic Journal, 44(4), 321-9.

Vigneshwar Sambandam, T., Sindhu R. (2017). Taurodontism a challenge in endodontics: Acase report. Sambandam and Ramesh: Taurodontism a challenge in endodontics. Journal of Advanced Pharmacy Education \& Research, 7(3), 349-351.

Nair, P. R., Sjögren, U., Krey, G., Kahnberg, K.-E., \& Sundqvist, G. (1990). Intraradicular bacteria and fungi in root-filled, asymptomatic human teeth with therapy-resistant periapical lesions: A long-term light and electron microscopic follow-up study. Journal of Endodontics, 16(12), 580-8.

Nanci, A. (2012). Ten Cate's Oral Histology: Development, Structure, and Function (p. 411). Mosby: St. Louis, Mo, USA.

Nie, Q., \& Lin, J. (1999). Comparison of intermaxillary tooth size discrepancies among different malocclusion groups. American Journal of Orthodontics and Dentofacial Orthopedics, 116(5), 539-44.

Noor, N., Maxood, A., \& Kaleem, K. (2008). Cross-sectional analysis of endodontic failure in PIMS. Pak Oral Dent J., 28, 99-102.

Seltzer, S., Bender, I., \& Turkenkopf, S. (1963). Factors affecting successful repair after root canal therapy. The Journal of the American Dental Association, 67(5), 651-62.

Setzer, F., \& Kim, S. (2014). Comparison of long-term survival of implants and endodontically treated teeth. Journal of Dental Research, 93(1), 19-26.

Siqueira, J. F., Rôças, I. N., \& Ricucci, D. (2019). Internal tooth anatomy and root canal instrumentation. The Root Canal Anatomy in Permanent Dentition: Springer (pp. 277-302).

Farbod, M., Bolhari, B. (2018). Regenerative endodontics: a review on clinical protocols and subsequent coronal discoloration. Annals of Dental Specialty, 6(1), 71-76.

Sjögren, U., Hägglund, B., Sundqvist, G., \& Wing, K. (1990). Factors affecting the long-term results of endodontic treatment. Journal of Endodontics, 16(10), 498-504.

Strindberg, L. Z. (1956). The dependence of the results of pulp therapy on certain factors-an analytical study based on radiographic and clinical follow-up examination. Acta Odontol Scand, 14, 1-175. 
Sundqvist, G., Figdor, D., Persson, S., \& Sjögren, U. (1998). Microbiologic analysis of teeth with failed endodontic treatment and the outcome of conservative re-treatment. Oral Surgery, Oral Medicine, Oral Pathology, Oral Radiology, and Endodontology, 85(1), 86-93.

Touré, B., Faye, B., Kane, A. W., Lo, C. M., Niang, B., \& Boucher, Y. (2011). Analysis of reasons for extraction of endodontically treated teeth: A prospective study. Journal of Endodontics, 37(11), 1512-5.

Tzimpoulas, N. E., Alisafis, M. G., Tzanetakis, G. N., \& Kontakiotis, E. G. (2012). A prospective study of the extraction and retention incidence of endodontically treated teeth with uncertain prognosis after endodontic referral. Journal of Endodontics, 38(10), 1326-9.

Weiger, R., \& Axmann-Krcmar, D. (1998). Prognosis of conventional root canal treatment reconsidered. Dental Traumatology, 14(1), 1-9.

Zadik, Y., Sandler, V., Bechor, R., \& Salehrabi, R. (2008). Analysis of factors related to extraction of endodontically treated teeth. Oral Surgery, Oral Medicine, Oral Pathology, Oral Radiology, and Endodontology, 106(5), e31-e5.

\section{Copyrights}

Copyright for this article is retained by the author(s), with first publication rights granted to the journal.

This is an open-access article distributed under the terms and conditions of the Creative Commons Attribution license (http://creativecommons.org/licenses/by/4.0/). 